Paduch Jarosław, Syrowatko Agnieszka, Żołnierczuk Michal. The importance of socio-demographic determinants and selected personality traits in shaping Poles' attitudes towards vaccination against COVID-19. Journal of Education, Health and Sport. 2021;11(10):74-87. eISSN 2391-8306. DOI http://dx.doi.org/10.12775/JEHS.2021.11.10.007

https://apcz.umk.pl/JEHS/article/view/JEHS.2021.11.10.007

https://zenodo.org/record/5579237

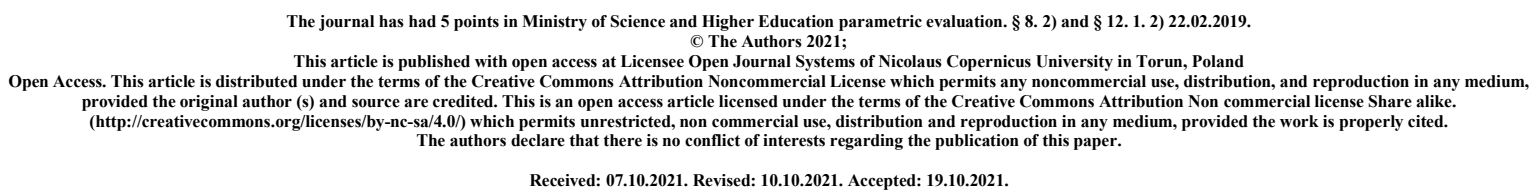

The importance of socio-demographic determinants and selected personality traits in shaping Poles' attitudes towards vaccination against COVID-19

\title{
Jarosław Paduch
}

Student at the Faculty of Medicine and Dentistry at Pomeranian Medical University: Szczecin, PL

\section{Agnieszka Syrowatko}

Master of Psychology, Student at Health Sciences Department at Pomeranian Medical University: Szczecin, PL

\section{Michał Żołnierczuk}

Student at the Faculty of Medicine and Dentistry at Pomeranian Medical University: Szczecin, PL

\begin{abstract}
Objective: The aim of this study is to determine the level of particular personality traits and attitudes of Poles towards immunization, including against COVID-19, and to analyze potential predictors of these attitudes.

Materials and methods: The online survey, conducted in September and October 2021, included 1466 individuals $(50.6 \%$ female) aged 18 to 80 years $(\mathrm{M}=42.81 ; \mathrm{SD}=12.46)$. The anonymous and voluntary online survey included original questions on attitudes toward immunization, including COVID-19 vaccination, rated on a 1-7 scale, past occurrence of NOP, and the Polish adaptation of the Ten Item Personality Inventory (TIPI)-TIPI-PL test.

Results: It was shown that significant predictors of the level of acceptance of immunization were female gender, size of residence, education and past occurrence of NOP. In case of personality traits it was agreeableness, emotional stability and openness to experience. Sources of knowledge about vaccination were also significantly related: friends' opinions, Internet and experts' opinions. A higher level of agreeableness and openness to experience was correlated with a higher level of acceptance of vaccinations, whereas a higher level of emotional stability was correlated with a lower level of acceptance of vaccinations. Female
\end{abstract}


gender, higher education and size of town of residence predisposed to acceptance of immunizations, whereas occurrence of vaccine adverse effect predisposed to low level of acceptance.

Key words: COVID-19, Big Five, TIPI-PL, vaccine acceptance, personality traits

\section{Admission}

COVID-19 (coronavirus disease 2019) is an infectious disease caused by SARS-CoV-2 (severe acute respiratory syndrome coronavirus 2) virus, belonging to the beta-coronavirus genus Coronaviridae. Infection with the new coronavirus spreads via droplets. It can be asymptomatic or mild, with typical symptoms of upper respiratory tract infections, such as fever, cough, or shortness of breath. Additionally, there may be headaches, muscle aches, nausea, vomiting, diarrhea, changes in the sense of smell and taste, or mild pneumonia with "frosted glass" changes. Moderate infection is characterized by dyspnoea, blood oxygen saturation levels below 93\%, respiratory rates exceeding $30 / \mathrm{min}$, arterial oxygen partial pressure to inhaled oxygen ratio below 300. Severe symptoms of acute respiratory distress syndrome (ARDS) develop, followed by multiple organ dysfunction syndrome (MODS) and death. Patients with moderate and severe COVID-19 require specialist treatment in an intensive care unit, in a facility equipped with high-flow oxygen therapy devices and ventilators [1].

The first cases of infections with the new virus were reported in the Wuhan province of the People's Republic of China in December 2019 [2]. The first diagnosed case of COVID-19 in Poland took place on March 4, 2020 [3]. On March 11, 2020, the World Health Organization (WHO) issued a statement on the global COVID-19 pandemic. There were then 118 thousand. COVID-19 cases in 114 countries and 4,291 deaths [4].

By 22.09.2021, due to the SARS-COV 2 (COVID-19) virus epidemic, 75,523 people had died in Poland, and the total number of infections since 04.03.2020 was 2,899,888 [5]. According to WHO, by 21.09 .21 there were 4,697,099 deaths globally and the total number of infections was $228,807,631$ [6].

On March 20. 2020. the state of the COVID-19 epidemic was officially introduced in Poland. A few days later, the first legal regulations came into force, imposing restrictions to slow down the spread of the virus. These included, among others: restrictions on free movement (excluding commuting to work, grocery stores and pharmacies), closing educational institutions, limiting the number of places occupied by public transport, and a ban on assembly. In addition, in public places, such as gyms, cinemas, theaters, discos, places of religious worship, sports facilities, bars, restaurants, shopping malls and shops, there was a significant reduction in the number of people staying. All moving persons were required to wear protective masks or helmets. Other measures were also recommended to prevent the spread of the virus - washing and disinfecting hands, maintaining social distancing, and reporting distressing symptoms to the doctor as soon as they appear. Patients with a positive PCR test result confirming active COVID-19 infection were isolated, and people who had direct contact with sick people were quarantined. For breaking the rules of isolation or quarantine, there was a fine of 5-30 thousand zlotys [7]. These actions, although necessary, had a negative impact on the Polish economy. The biggest losses were suffered by the following industries: catering, hotel and transport. Many small and micro enterprises closed down because they did not have sufficient resources to survive in the market.

Hospital wards were overcrowded, it was necessary to limit, and temporarily suspend, all scheduled procedures. Many patients did not have access to specialist care [9]. 
Despite the introduction of numerous sanitary restrictions, the infection rates remained high. It was also necessary to introduce preventive vaccinations. They are one of the most effective methods of preventing viral infections, and their effectiveness has been confirmed by numerous studies [10] [11] [12].

An excellent example of the effectiveness of preventive vaccination is the event that took place on May 8, 1980, when the World Health Assembly - the highest decision-making body of the World Health Organization (WHO) announced the complete eradication of smallpox (variola vera) - a viral infectious disease, which, like COVID-19, was transmitted by airborne droplets, thanks to an extensive vaccination program and the isolation of infected people. The mortality for the unvaccinated, depending on the form, ranged from 30 to $95 \%$, while the mortality of the vaccinated only about $3 \%$. The last described case of this disease took place in 1978 [13].

The mRNA vaccine COMIRNATY by Pfizer was the first to become available in Poland on December 27, 2020 [14]. The following preparations were: Moderna's Spikevax, Astra Zeneca's vector Vaxzevria vaccine, and Johnson \& Johnson's vector COVID-19 Vaccine [15]. As of September 16. 2021. 36773182 vaccinations against COVID-19 have been carried out in Poland, of which 19123432 people have been fully vaccinated with the number of doses recommended by the manufacturer. According to statistics, from the moment of introducing vaccines to the Polish market until mid-June 2021, the number of vaccinations performed per day increased, reaching the number of 652371 vaccinations per day. After this period, until September 2021, this number dropped to 20349 vaccinations performed every day [16]

Table 1. Efficacy of individual vaccines in the prevention of severe COVID-19 available in Poland by WHO.

\begin{tabular}{|l|l|}
\hline TYPE OF VACCINE & VACCINE EFFECTIVENESS \\
\hline COMIRNATE mRNA, Pfizer & $95 \%$ \\
\hline Spikevax mRNA, Moderna & $94.1 \%$ \\
\hline Vaxzevria, Astra Zeneca & $63 \%$ \\
\hline COVID-19 Vaccine, Johnson \& Johnson & $67 \%$ \\
\hline
\end{tabular}

Each drug, including vaccines, is associated with the possibility of side effects. 15,144 people reported postvaccination adverse events following the COVID-19 vaccine, which is approximately $0.041 \%$ of all doses taken. On September 25, 2021, about half of Poles were fully vaccinated.The most common adverse reactions that may occur with the vaccination against COVID-19 are fever, fatigue, headache, muscle aches, chills, diarrhea and injection site pain. The chance of serious side effects such as anaphylactic shock depends on the type of vaccine you receive, but it is extremely low. All side effects are monitored and reported by healthcare professionals[17].

A low level of implantation is determined by many factors. Research on the determinants of influenza vaccination indicates an important role for society's awareness, apart from the systemic solutions introduced by the state. In the case of influenza, which, like COVID-19, is a disease caused by viruses and transmitted by airborne droplets, important factors are knowledge about the disease itself, its complications and the role of vaccination in preventing infections.[18].

Anti-vaccination attitudes are a frequent phenomenon, not only against COVID-19 vaccinations, but also against vaccinations included in the vaccination calendar. Vaccine 
opponents are working hard to show a link between vaccine ingredients and the incidence of disease or death. These people indicate the superiority of the natural exposure to the pathogen over the preparation protecting against an infectious disease[19].Such attitudes can be influenced by psychosocial factors (e.g. loneliness or specific religious beliefs), psychological and characterological factors. In the latter, anxiety and the features of obsessive or paranoid thinking are of major importance. In the case of character traits, low self-esteem or too high magnitude may be important[20].

Personality traits are the basic variables used to describe it. They are not observable by themselves. Their existence can be inferred on the basis of the behavior observed in the individual. These features determine the tendency to react in a certain way[21].

One of the models describing personality is the five-factor model of the "Big Five", distinguishing five features: neuroticism, extraversion, openness to experience, agreeableness and conscientiousness [22]. According to this model, the above-mentioned features are supracultural and supra-demographic dimensions, allowing for the full characterization of the personality [23].

The trait of extraversion is characterized by a tendency to social interactions and experiencing positive emotions. People with a high level of this trait are most often cordial, friendly and optimistic.

Agreeableness indicates a willingness to help, honesty, modesty and affection towards other people. People with a high level of conscientiousness will be characterized by scrupulousness, diligence, prudence and reliability.

Emotional stability determines your susceptibility to feeling negative emotions. Individuals with high levels of this trait struggle with stressful situations without experiencing fear or irritation. The last factor is openness to experience. This feature indicates a tendency to look for new life experiences and a tolerance towards new things [24].

It can be assumed that certain personality factors will have a significant impact on the attitude towards vaccinations, both for preparations included in the mandatory vaccination schedule and preparations used in the prevention of infection and severe COVID-19 courses. The lower the level of openness to experience, the more often individuals will be reluctant to vaccinate. However, with a higher level of conscientiousness, pro-vaccination declarations will appear more often. The aim of this study is to determine whether there are relationships between the given variables and to establish the ratio of people supporting compulsory preventive vaccinations, included in the vaccination calendar, to preparations used in vaccinations against COVID-19.

\section{Materials and methods}

\section{Study group}

1483 people took part in the study, and the results of 17 people were excluded from further analyzes due to significant gaps in the data. Therefore, 1466 people were included in the analyzed group, of which 742 women $(50.6 \%)$ and $724(49.4 \%)$ men. They were tested at the age of 18 to 80 years, the mean age was $\mathrm{M}=42.81$ ( $\mathrm{SD}=12.46)$. The exact sociodemographic characteristics of the study group are presented in Table 1. There were significantly more inhabitants among the respondents cities with more than 100,000 residents. 
Table 2: Sociodemographic characteristics of the group.

\begin{tabular}{|c|c|c|c|c|c|c|}
\hline \multirow{2}{*}{ Variables } & \multirow{2}{*}{$\begin{array}{l}\text { The whole } \\
\text { group } \\
\begin{array}{l}\text { M (SD) / N } \\
(\%)\end{array}\end{array}$} & \multirow{2}{*}{\begin{tabular}{|l} 
Women \\
$\begin{array}{l}\text { M (SD) / N } \\
(\%)\end{array}$
\end{tabular}} & \multirow{2}{*}{\begin{tabular}{|l|} 
Men \\
$\begin{array}{l}\text { M (SD) / N } \\
(\%)\end{array}$
\end{tabular}} & \multicolumn{3}{|c|}{ Group comparison } \\
\hline & & & & $\mathbf{Z} * / \mathbf{X} \mathbf{2}$ & df & $\mathbf{p}$ \\
\hline Age & $\begin{array}{l}42.81 \\
(12.46)\end{array}$ & $\begin{array}{l}43.17 \\
(13.21)\end{array}$ & $\begin{array}{l}42.44 \\
(11.64)\end{array}$ & $-1.603 *$ & - & 0.109 \\
\hline \multicolumn{7}{|l|}{ Education } \\
\hline basic & $11(0.8 \%)$ & $4(0.5 \%)$ & $7(1 \%)$ & \multirow[t]{5}{*}{$2,040,889$} & \multirow[t]{5}{*}{4} & \multirow[t]{5}{*}{$<0.001$} \\
\hline professional & $33(2.3 \%)$ & $14(1.9 \%)$ & $19(2.6 \%)$ & & & \\
\hline medium & $\begin{array}{l}343 \\
(23.4 \%)\end{array}$ & $\begin{array}{l}153 \\
(20.6 \%)\end{array}$ & $\begin{array}{l}190 \\
(26.2 \%)\end{array}$ & & & \\
\hline $\begin{array}{l}\text { incomplete higher } \\
\text { education (BA, } \\
\text { still studying) }\end{array}$ & $135(9.2 \%)$ & $83(11.2 \%)$ & $52(7.2 \%)$ & & & \\
\hline higher full (MA +) & $\begin{array}{l}944 \\
(64.4 \%)\end{array}$ & $\begin{array}{l}488 \\
(65.8 \%)\end{array}$ & $456(63 \%)$ & & & \\
\hline \multicolumn{7}{|l|}{ Domicile } \\
\hline $\begin{array}{l}\text { 2. city } \\
\text { up to } \\
\mathbf{2 0 , 0 0 0} \\
\text { residents }\end{array}$ & $\begin{array}{l}356 \\
(24.3 \%)\end{array}$ & $\begin{array}{l}182 \\
(24.5 \%)\end{array}$ & $174(24 \%)$ & 796.739 & 3 & $<0.001$ \\
\hline $\begin{array}{ll}\text { 3. } & \text { city of } \\
\mathbf{2 0 - 5 0} & \\
\text { thousand } \\
\text { residents }\end{array}$ & $\begin{array}{l}177 \\
(12.1 \%)\end{array}$ & $96(12.9 \%)$ & $81(11.2 \%)$ & & & \\
\hline
\end{tabular}




\begin{tabular}{|c|c|c|c|c|c|c|}
\hline \begin{tabular}{l} 
4. city \\
\multicolumn{1}{c}{ with } \\
\\
$\mathbf{5 0 - 1 0 0}$ \\
thousand \\
inhabitants
\end{tabular} & $123(8.4 \%)$ & $71(9.6 \%)$ & $52(7.2 \%)$ & & & \\
\hline \begin{tabular}{l} 
5. city \\
\multicolumn{1}{c}{ with } \\
over \\
$\mathbf{1 0 0 , 0 0 0}$ \\
residents
\end{tabular} & $\begin{array}{l}810 \\
(55.3 \%)\end{array}$ & $393(53 \%)$ & $\begin{array}{l}417 \\
(57.6 \%)\end{array}$ & & & \\
\hline \multicolumn{7}{|l|}{ Marital status } \\
\hline free & $\begin{array}{l}290 \\
(19.8 \%)\end{array}$ & $\begin{array}{l}143 \\
(19.3 \%)\end{array}$ & $\begin{array}{l}147 \\
(20.3 \%)\end{array}$ & 749.678 & 3 & $<0.001$ \\
\hline $\begin{array}{l}\text { in an informal } \\
\text { relationship }\end{array}$ & $\begin{array}{l}260 \\
(17.7 \%)\end{array}$ & $\begin{array}{l}147 \\
(19.8 \%)\end{array}$ & $\begin{array}{l}113 \\
(15.6 \%)\end{array}$ & & & \\
\hline $\begin{array}{l}\text { in a formal } \\
\text { relationship }\end{array}$ & $\begin{array}{l}805 \\
(54.9 \%)\end{array}$ & $\begin{array}{l}380 \\
(51.2 \%)\end{array}$ & $\begin{array}{l}425 \\
(58.7 \%)\end{array}$ & & & \\
\hline divorced & $111(7.6 \%)$ & $72(9.7 \%)$ & $39(5.4 \%)$ & & & \\
\hline
\end{tabular}

\section{The course of the study}

The study was conducted in the period 08.09.2021 - 30.09.2021.The data was collected using an on-line questionnaire. The link to the survey has been disseminated hassocial networks (Facebook, Twitter). Participation in the study was voluntary and anonymous. The survey instruction recommended that the respondent should choose only one answer in each question that was most consistent with his / her convictions.

\section{Research tools}

An original questionnaire was used in the study and a standardized psychological questionnaire:

1. Personality dimensions were measured using the Polish adaptation of the Ten Item Personality Inventory (TIPI) - TIPI-PL test by: Sorokowska, Słowińska, Zbieg, Sorokowski. Cronbah's alpha coefficients range from 0.45 to 0.83 .. They are the lowest for the Openness to Experience scale and the highest for the Emotional Stability scale. The tool consists of 10 self-report items assessed ona scale from 1 to 7 . It measures the severity of 5 personality traits described in the "Big Five" model 
(neuroticism, extraversion, conscientiousness, openness to experience, agreeableness) [22]. The severity of each of the traits is assessed on the basis of the sum of points. [23]

2. Author's personal questionnaire consisting of 13 questions: 6 sociodemographic questions (gender, age, level of education, size of the place of residence, marital status,),

1.question about the occurrence of an adverse vaccine reaction, 2.questions about COVID-19 disease, 1.Question about willingness to vaccinate and the type of selected preparation, 1. question about the sources of knowledge on the subject of protective vaccinations COVID- 19 .

\section{Statistical analysis}

The results were quantified using the IBM SPSS package Statistics v. 28. The following techniques of statistical description were used: Shapiro-Wilk test to assess the normality of distributions, Spearman's rank correlation analysis, tests for comparing two independent groups (Mann-Whitney $U$ test and chi-Pearson square), and hierarchical regression model. The $p$ value $<0.05$ was

\section{Results}

Table 3. Personality traits based on the TIPI questionnaire (online form)

\begin{tabular}{|l|l|l|l|l|l|}
\hline \multirow{2}{*}{ Variables } & $\begin{array}{l}\text { The whole } \\
\text { group }\end{array}$ & Women & Men & \multicolumn{2}{l|}{ Group comparison } \\
\cline { 2 - 6 } & $\begin{array}{l}\text { min-max M } \\
\text { (SD) }\end{array}$ & $\begin{array}{l}\text { min-max M } \\
\text { (SD) }\end{array}$ & $\begin{array}{l}\text { min-max } \\
\text { M (SD) }\end{array}$ & WITH & $\mathrm{p}$ \\
\hline Extroversion & $\begin{array}{l}2-14 \\
10.93(2.95)\end{array}$ & $\begin{array}{l}2-1,411.00 \\
(2.97)\end{array}$ & $\begin{array}{l}2-1410.87 \\
(2.94)\end{array}$ & -1.178 & 0.239 \\
\hline Amicability & $\begin{array}{l}3-1411.17 \\
(2.22)\end{array}$ & $\begin{array}{l}3-1411.36 \\
(2.24)\end{array}$ & $\begin{array}{l}3-1410.98 \\
(2.19)\end{array}$ & -3.847 & $<0.001$ \\
\hline Scrupulousness & $\begin{array}{l}2-1411.31 \\
(2.4)\end{array}$ & $\begin{array}{l}2-1411.68 \\
(2.33)\end{array}$ & $\begin{array}{l}2-1410.93 \\
(2.41)\end{array}$ & -6.877 & $<0.001$ \\
\hline Emotional stability & $\begin{array}{l}2-149.91 \\
(3.06)\end{array}$ & $\begin{array}{l}2-149.44 \\
(3.15)\end{array}$ & $\begin{array}{l}2-1410.40 \\
(2.88)\end{array}$ & 5.876 & $<0.001$ \\
\hline $\begin{array}{l}\text { Openness } \\
\text { experience }\end{array}$ & $\begin{array}{l}2-1410.09 \\
(2.35)\end{array}$ & $\begin{array}{l}2-1410.24 \\
(2.39)\end{array}$ & $\begin{array}{l}3-149.94 \\
(2.30)\end{array}$ & -2.678 & 0.007 \\
\hline
\end{tabular}


Table 4. Incidence of serious adverse reactions after vaccination, previous COVID-19 infection (confirmed by PCR test) and hospitalization due to COVID-19 in the study group.

\begin{tabular}{|c|c|c|c|c|c|c|}
\hline \multirow[t]{2}{*}{ Variables } & \multirow{2}{*}{$\begin{array}{l}\text { The whole } \\
\text { group } \\
\text { M (SD) / N } \\
\text { (\%) }\end{array}$} & \multirow{2}{*}{$\begin{array}{l}\text { Women } \\
\begin{array}{l}\text { M (SD) / N } \\
(\%)\end{array}\end{array}$} & \multirow{2}{*}{$\begin{array}{l}\text { Men } \\
\begin{array}{l}\text { M (SD) / N } \\
(\%)\end{array}\end{array}$} & \multicolumn{3}{|c|}{ Group comparison } \\
\hline & & & & $\mathbf{X} 2$ & df & $\mathbf{p}$ \\
\hline \multicolumn{7}{|l|}{$\begin{array}{lr}\text { An } & \text { undesirable } \\
\text { severe } & \text { vaccine } \\
\text { reaction } & \text { has } \\
\text { occurred } & \end{array}$} \\
\hline Yes & $66(4.5 \%)$ & $34(4.6 \%)$ & $32(4.4 \%)$ & 1213.885 & 1 & $<0.001$ \\
\hline No & $1400(95 \%)$ & $\begin{array}{l}706 \\
(95.4 \%)\end{array}$ & $\begin{array}{l}692 \\
(95.6 \%)\end{array}$ & & & \\
\hline \multicolumn{7}{|l|}{$\begin{array}{l}\text { Previous COVID- } \\
19 \text { infection } \\
\text { (confirmed by } \\
\text { PCR test) }\end{array}$} \\
\hline Yes & $\begin{array}{l}354 \\
(24.1 \%)\end{array}$ & $\begin{array}{l}166 \\
(22.4 \%)\end{array}$ & $188(26 \%)$ & 391,926 & 1 & $<0.001$ \\
\hline No & $\begin{array}{l}1,112 \\
(75.9 \%)\end{array}$ & $\begin{array}{l}576 \\
(77.6 \%)\end{array}$ & $536(74 \%)$ & & & \\
\hline \multicolumn{7}{|l|}{$\begin{array}{l}\text { Hospitalization } \\
\text { due to COVID-19 } \\
\text { infection }\end{array}$} \\
\hline Yes & $7(0.5 \%)$ & $4(0.5 \%)$ & $3(0.4 \%)$ & 1438,134 & 1 & $<0.001$ \\
\hline No & $\begin{array}{l}1,459 \\
(99.5 \%)\end{array}$ & $\begin{array}{l}738 \\
(99.5 \%)\end{array}$ & $\begin{array}{l}721 \\
(99.6 \%)\end{array}$ & & & \\
\hline
\end{tabular}


Table 5. Respondents' attitudes to the validity of preventive vaccinations.

\begin{tabular}{|c|c|c|c|c|c|}
\hline \multirow{2}{*}{$\begin{array}{l}\text { To what extent do } \\
\text { you agree with the } \\
\text { following statement }\end{array}$} & \multirow{2}{*}{$\begin{array}{l}\text { The whole } \\
\text { group } \\
\begin{array}{l}\text { min-max } \mathrm{M} \\
\text { (SD) }\end{array}\end{array}$} & \multirow{2}{*}{$\begin{array}{l}\text { Women } \\
\text { min-max M } \\
\text { (SD) }\end{array}$} & \multirow{2}{*}{$\begin{array}{l}\text { Men } \\
\text { min-max } \\
\text { M (SD) }\end{array}$} & \multicolumn{2}{|c|}{ Group comparison } \\
\hline & & & & WITH & $\mathrm{p}$ \\
\hline $\begin{array}{l}\text { Preventive } \\
\text { vaccinations } \\
\text { included in the } \\
\text { compulsory } \\
\text { vaccination } \\
\text { schedule * are } \\
\text { required. " } \\
\text { against: hepatitis } \mathrm{B}, \\
\text { tuberculosis, } \\
\text { rotavirus, } \\
\text { diphtheria, tetanus, } \\
\text { pertussis, } \\
\text { poliomyelitis, Hib } \\
\text { and pneumococcal]. }\end{array}$ & $\begin{array}{l}1-7 \\
6.5(1.24)\end{array}$ & $\begin{array}{l}1-7 \\
6.61(1.15)\end{array}$ & $\begin{array}{l}1-7 \\
6.38(1.31)\end{array}$ & -5.826 & $<0.001$ \\
\hline $\begin{array}{lr}\text { Preventive } & \\
\text { vaccinations } & \text { against } \\
\text { COVID-19 } & \text { are } \\
\text { needed. } & \end{array}$ & $\begin{array}{l}1-7 \\
5.35(2.42)\end{array}$ & $\begin{array}{l}1-7 \\
5.8(2.15)\end{array}$ & $\begin{array}{l}1-7 \\
4.88(2.58)\end{array}$ & -7.203 & $<0.001$ \\
\hline
\end{tabular}

Table 6.

\begin{tabular}{|c|c|c|c|c|c|c|c|c|}
\hline \multirow[t]{2}{*}{$\begin{array}{l}\text { Reactions } \\
\text { positive }\end{array}$} & \multicolumn{2}{|c|}{$\begin{array}{l}\text { Model 1; } \\
\text { R2 }=0.838\end{array}$} & \multicolumn{2}{|c|}{$\begin{array}{l}\text { Model 2; } \\
\text { R2 =0.845 }\end{array}$} & \multicolumn{2}{|c|}{$\begin{array}{l}\text { Model 3; } \\
\text { R2 =0.846 }\end{array}$} & \multicolumn{2}{|c|}{$\begin{array}{l}\text { Model 4; } \\
\text { R2 =0.859 }\end{array}$} \\
\hline & beta & $\mathrm{p}$ & beta & $\mathrm{p}$ & beta & $\mathrm{p}$ & beta & $\mathrm{p}$ \\
\hline Age & 0.581 & $\begin{array}{l}<0.00 \\
1\end{array}$ & 0.521 & $<0.001$ & 0.514 & $<0.001$ & 0.420 & $<0.001$ \\
\hline $\operatorname{sex}$ & -0.069 & 0.017 & -0.069 & 0.022 & -0.066 & 0.029 & -0.024 & 0.429 \\
\hline Education & 0.279 & $\begin{array}{l}<0.00 \\
1\end{array}$ & 0.162 & $<0.001$ & 0.171 & $<0.001$ & 0.134 & 0.002 \\
\hline Domicile & 0.087 & $\begin{array}{l}<0.00 \\
1\end{array}$ & 0.064 & 0.014 & 0.063 & 0.017 & 0.060 & 0.017 \\
\hline Marital status & 0.054 & 0.117 & 0.036 & 0.301 & 0.037 & 0.281 & 0.013 & 0.695 \\
\hline Extroversion & & & -0.032 & 0.521 & -0.030 & 0.548 & -0.037 & 0.438 \\
\hline Amicability & & & 0.245 & $<0.001$ & 0.236 & $<0.001$ & 0.240 & $<0.001$ \\
\hline
\end{tabular}




\begin{tabular}{|c|c|c|c|c|c|c|}
\hline Scrupulousness & 0.097 & 0.059 & 0.103 & 0.043 & 0.078 & 0.113 \\
\hline $\begin{array}{l}\text { Emotional } \\
\text { stability }\end{array}$ & -0.234 & $<0.001$ & -0.227 & $<0.001$ & -0.201 & $<0.001$ \\
\hline $\begin{array}{l}\text { Openness to } \\
\text { experience }\end{array}$ & 0.140 & 0.004 & 0.143 & 0.003 & 0.139 & 0.003 \\
\hline UPVR speech * & & & -0.041 & $<0.001$ & -0.034 & $<0.001$ \\
\hline $\begin{array}{l}\text { Previous } \\
\text { COVID-19 } \\
\text { infection }\end{array}$ & & & -0.014 & 0.235 & -0.014 & 0.232 \\
\hline $\begin{array}{l}\text { Hospitalization } \\
\text { for COVID-19 }\end{array}$ & & & 0.009 & 0.404 & 0.007 & 0.463 \\
\hline $\begin{array}{l}\text { Medical } \\
\text { literature ** }\end{array}$ & & & & & -0.037 & 0.006 \\
\hline $\begin{array}{l}\text { Expert opinions } \\
* *\end{array}$ & & & & & 0.227 & $<0.001$ \\
\hline $\begin{array}{l}\text { Friends' } \\
\text { opinions } * *\end{array}$ & & & & & -0.044 & $<0.001$ \\
\hline Internet** & & & & & -0.075 & $<0.001$ \\
\hline
\end{tabular}

\section{* undesirable post-vaccination reaction \\ ** Declared source of knowledge about vaccinations.}

In table 5. contains the results of hierarchical regression analysis, taking into account four blocks of variables: sociodemographic, personality, medical, and sources of knowledge about vaccination used by respondents, explaining attitudes towards preventive vaccination, including vaccination against COVID-19. The first model referring only to sociodemographic variables indicated a significant percentage of the variance of the explained variable. All socio-demographic variables, except for the marital status of the respondents, were statistically significant $(\mathrm{p}<0.05)$. After accounting for personality traits in the second model, R2 increased slightly, and the model explained nearly $85 \%$ of the total variance of the results. Socio-demographic variables, excluding marital status, maintained their significance ( $p$ $<0.05$ ), and moreover, three personality traits: agreeableness, emotional stability and openness to experience, turned out to be significant predictors $(\mathrm{p}<0.05)$. Taking into account another variable did not increase R2 and the range of explained variance. As in the second model, it was around $85 \%$. Sociodemographic and personality variables still maintained their significance $(p<0.05)$. Moreover, the medical factor of NOP turned out to be a significant predictor $(p<0.001)$. The inclusion in the fourth model of the variable, which were the sources of knowledge about vaccination, resulted in an increase in the total variance of the results by $1 \%$. The other variables still maintained their significance $(\mathrm{p}<0.05)$. In addition, expert opinions, friends' opinions and the Internet $(\mathrm{p}<0.001)$ turned out to be particularly important predictors of the explained variable. Taking into account another variable did not increase R2 and the range of explained variance. As in the second model, it was around $85 \%$. 
Socio-demographic and personality variables still maintained their significance $(\mathrm{p}<0.05)$. Moreover, the medical factor of NOP turned out to be a significant predictor $(p<0.001)$. The inclusion in the fourth model of the variable, which were the sources of knowledge about vaccination, resulted in an increase in the total variance of the results by $1 \%$. The other variables still maintained their significance $(\mathrm{p}<0.05)$. In addition, expert opinions, friends' opinions and the Internet $(\mathrm{p}<0.001)$ turned out to be particularly important predictors of the explained variable. Taking into account another variable did not increase R2 and the range of explained variance. As in the second model, it was around $85 \%$. Socio-demographic and personality variables still maintained their significance $(\mathrm{p}<0.05)$. Moreover, the medical factor of NOP turned out to be a significant predictor $(\mathrm{p}<0.001)$. The inclusion in the fourth model of the variable, which were the sources of knowledge about vaccination, resulted in an increase in the total variance of the results by $1 \%$. The other variables still maintained their significance $(\mathrm{p}<0.05)$. In addition, expert opinions, friends' opinions and the Internet ( $p$ $<0.001$ ) turned out to be particularly important predictors of the explained variable. Moreover, the medical factor of NOP turned out to be a significant predictor $(\mathrm{p}<0.001)$. The inclusion in the fourth model of the variable, which were the sources of knowledge about vaccination, resulted in an increase in the total variance of the results by $1 \%$. The other variables still maintained their significance $(\mathrm{p}<0.05)$. In addition, expert opinions, friends' opinions and the Internet ( $\mathrm{p}<0.001)$ turned out to be particularly important predictors of the explained variable. Moreover, the medical factor of NOP turned out to be a significant predictor $(\mathrm{p}<0.001)$. The inclusion in the fourth model of the variable, which were the sources of knowledge about vaccination, resulted in an increase in the total variance of the results by $1 \%$. The other variables still maintained their significance $(\mathrm{P}<0.05)$. In addition, expert opinions, friends' opinions and the Internet $(\mathrm{p}<0.001)$ turned out to be particularly important predictors of the explained variable.

The obtained results indicate that age, sex, education and place of residence were of significant importance for the willingness to vaccinate against COVI-19. The female gender was the most significant predictor $(\mathrm{p}<0.001)$. Among the personality indicators, agreeableness and emotional stability were particularly important $(\mathrm{p}<0.001)$. At the same time, along with the increase in emotional stability, the degree of acceptance of preventive vaccinations decreased. This means that people accepting vaccinations against COVID-19 are more likely to help others.

History of NOP was a significant predictor among the factors composing the medical data $(\mathrm{p}$ $<0.001)$.Following NOP, the degree of acceptance of preventive vaccinations decreased. On the other hand, analyzing the relationship between the sources of knowledge about preventive vaccinations and the declared willingness to hook up, it has been shown that the important indicators are the opinions of friends, experts' opinions and the Internet. People whose source of knowledge were the opinions of experts showed a higher degree of acceptance of preventive vaccinations, while respondents basing their knowledge on the opinions of friends and the Internet were characterized by a low level of their acceptance.

\section{Discussion of the results}

The study was aimed at determining whether there are statistically significant relationships between pomBetween the level of extroversion, openness to experience, agreeableness and conscientiousness, and the degree of acceptance of preventive vaccinations against COVID19. Among the factors that made up the personality, agreeableness and emotional stability were the most important. The higher the level of agreeableness presented by a given unit, the more it agreed with the statement that "protective vaccinations against COVID-19 are needed". On the other hand, people who are more emotionally stable, characterized by a low tendency 
to worry and timidity to a lesser extent agree with the above-mentioned statement. The other personality variables were not significant in predicting opinions about vaccinations [25].

There was also a correlation between the sex of the subjects and the degree of acceptance of preventive vaccinations. In the case of declaring the necessity of the idea of preventive vaccinations, female gender was an important predictor, however, attention is drawn to the need to be critical, due to the predominance of women who participated in the study, which is characteristic of online research, and which significantly limits the possibility of generalizing the results. Higher education of the respondents, both full and incomplete (student), and living in large and very large cities, were of significant importance in the acceptance of vaccinations. However, in this case, the data should also be strictly assessed due to the greater prevalence of students, people with higher education and residents of cities with 50,000 inhabitants. inhabitants and more in the study group.

People with NOP in the past showed lower acceptance of preventive vaccinations than those who did not report adverse symptoms.vaccinating.

The source of knowledge on vaccination also turned out to be an important indicator of vaccination acceptance. Those who consult the experts show more support for the idea of vaccination than those who do The sources of knowledge were the opinions of friends or the Internet [26].

Despite the fact that efforts were made to maintain the methodological correctness, the presented study has its limitations. It was based on a correlation model, which allows to show only significant relationships between the studied variables and the prediction of one variable based on the other, but it does not make it possible to make cause-and-effect inferences. against preventive vaccinations against COVID-19. In the future, it should be considered expanding the research on the issue, taking into account the implications, in order to potentially generalize the sample.

\section{References}

[1] Wang MY, Zhao R, Gao LJ et al. SARS-CoV-2: Structure, Biology, and Structure-Based Therapeutics Development. Front Cell Infect Microbiol. 2020;10:587269. Published 2020 Nov 25. doi:10.3389/fcimb.2020.587269.

[2] Baloch S, Baloch MA, Zheng T et al. The Coronavirus Disease 2019 (COVID-19) Pandemic. Tohoku J Exp Med. 2020 Apr;250(4):271-278. doi: 10.1620/tjem.250.271. PMID: 32321874.

[3] Ministerstwo Zdrowia. Pierwszy przypadek koronawirusa w Polsce, https://www.gov.pl/web/zdrowie/pierwszy-przypadek-koronawirusa-w-polsce (dostęp 04.03.2020).

[4] WHO. Director-General's opening remarks at the media briefing on COVID-19 - 11 March 2020". https:/www.who.int/director-general/speeches/detail/who-director-general-sopening-remarks-at-the-media-briefing-on-covid-19---11-march-2020 (dostęp: 18.09.2021).

[5] Ministerstwo Zdrowia. Raport zakażeń koronawirusem SARS-CoV-2. https://www.gov.pl/web/koronawirus/wykaz-zarazen-koronawirusem-sars-cov-

2?fbclid=IwAR3YVwNXVN_0DJ42eU7SUE0wwTgBQAHqd70P13Gdv1X-

kMdEYS4hMWG6mxI (dostęp 22.09.2021).

[6] WHO. Coronavirus (COVID-19) Dashboard". WHO; https://covid19.who.int/. (dostęp: 22.09.2021).

[7] Serwis Rzeczypospolitej Polskiej. Działania rządu, https://www.gov.pl/web/koronawirus/dzialania-rzadu. (dostęp 22.09.2021).

[8] Serwis Rzeczypospolitej Polskiej. Skutki COVID-19 dla polskiej gospodarki. https://www.gov.pl/web/oecd/skutki-covid-19-dla-polskiej-gospodarki (dostęp 11.08.2020). 
[9] Narodowy Fundusz Zdrowia. Centrala NFZ zaleca ograniczenie do niezbędnego minimum lub czasowe zawieszenie udzielania świadczeń wykonywanych planowo. https://www.nfz.gov.pl/aktualnosci/aktualnosci-centrali/udzielanie-swiadczen-opiekizdrowotnej-w-zwiazku-z-zapobieganiem-przeciwdzialaniem-i-zwalczaniem-covid-19zalecenia,7940.html. (dostęp 25.09.2021).

[10] Mahase E. Covid-19: Pfizer vaccine efficacy was 52\% after first dose and $95 \%$ after second dose, paper shows. BMJ. 2020 Dec 11;371:m4826. doi: 10.1136/bmj.m4826. PMID: 33310706.

[11] Knoll MD, Wonodi C. Oxford-AstraZeneca COVID-19 vaccine efficacy. Lancet. 2021 Jan 9;397(10269):72-74. doi: 10.1016/S0140-6736(20)32623-4. Epub 2020 Dec 8. PMID: 33306990; PMCID: PMC7832220.

[12] Baden LR, El Sahly HM, Essink B, et al. COVE Study Group. Efficacy and Safety of the mRNA-1273 SARS-CoV-2 Vaccine. N Engl J Med. 2021 Feb 4;384(5):403-416. doi: 10.1056/NEJMoa2035389. Epub 2020 Dec 30. PMID: 33378609 ; PMCID: PMC7787219.

[13] Heymann, Wilder-Smith. Successful smallpox eradication: what can we learn to control COVID-19?, Journal of Travel Medicine, Volume 27, Issue 4, May 2020, taaa090, https://doi.org/10.1093/jtm/taaa090.

[14] Serwis Rzeczypospolitej Polskiej. W Polsce ruszyły szczepienia przeciw COVID-19. https://www.gov.pl/web/szczepimysie/w-polsce-ruszyly-szczepienia-przeciw-covid-19--tohistoryczny-moment (dostęp 25.09.2021).

[15] Państwowy Zakład Higieny. Szczepionka przeciw COVID-19 https://szczepienia.pzh.gov.pl/szczepionki/covid-19-2. (dostęp 25.09.2021).

[16] Ministerstwo Zdrowia, Raport szczepień przeciwko COVID-19, https://www.gov.pl/web/szczepimysie/raport-szczepien-przeciwko-covid-19 (dostęp 25.09.2021).

[17] WHO. COVID-19 Vaccines. https://www.who.int/emergencies/diseases/novelcoronavirus-2019/covid-19-vaccines (dostęp 22.09.21).

[18] Agnieszka Dymek-Skoczyńska, Joanna Stanisławska, Elżbieta Drozd i inni. Szczepienia przeciw grypie u osób w wieku podeszłym -czynniki determinujące decyzję pacjentów. Nowiny Lekarskie 2012, 81, 1, 21-25 PRACE ORYGINALNE

[19] Marchewka, Majewska, Młynarczyk. Działalność ruchu antyszczepionkowego, rola środków masowego komunikowania oraz wpływ poglądów religijnych na postawę wobec szczepień ochronnych. Postępy Mikrobiologii, 54(2), 95-102.

[20] Maciej Żerdziński. Problem antyszczepionkowy względem covid:próba analizy postaw W kontekście postępowania. Psychiatria Online First 2021-09-22 DOI: 10.5603/PSYCH.a2021.003.

[21] Laguna Mariola, Bak Waclaw, Purc, Ewelina i inni. Krótki inwentarz osobowości TIPI-P w badaniach polskich. Roczniki Psychologiczne. 17. 403-419. (2014).

[22] Costa, Mccrae. (2012). The Five-Factor Model, Five-Factor Theory, and Interpersonal Psychology. In Handbook of Interpersonal Psychology: Theory, Research, Assessment, and Therapeutic Interventions (pp. 91-104). John Wiley and Sons. https://doi.org/10.1002/9781118001868.ch6.

[23] Sorokowska, Słowińska, Zbieg, i inni. Polska adaptacja testu Ten Item Personality Inventory (TIPI) - TIPI-PL - wersja standardowa $i$ internetowa. (2014). https://doi.org/10.1002/9781118001868.ch6.

[24] Zawadzki, Strelau, Szczepaniak i inni. Inwentarz Osobowości

NEO-FFI Paula T. Costy Jr i Roberta R. McCrea. Adaptacja polska. Warszawa: (2007).

Pracownia Testów Psychologicznych. 
[25] Lin FY, Wang CH. Personality and individual attitudes toward vaccination: a nationally representative survey in the United States. BMC Public Health. 2020;20(1):1759. Published 2020 Nov 23. doi:10.1186/s12889-020-09840-w.

[26] Guay M, Gosselin V, Petit G et al. Determinants of vaccine hesitancy in Quebec: a large population-based survey. Hum Vaccin Immunother. 2019;15(11):2527-2533. doi:10.1080/21645515.2019.1603563. 